\title{
KELIMPAHAN FITOPLANKTON PENYEBAB HAB (HARMFUL ALGAL BLOOM) DI PERAIRAN TELUK LAMPUNG PADA MUSIM BARAT DAN TIMUR
}

\section{The Abundance of Phytoplankton Causing HAB (Harmful Algal Bloom) in Lampung Bay during West and East Monsoon}

\author{
Giri Rohmad Barokah*, Ajeng Kurniasari Putri dan Gunawan \\ Pusat Penelitian dan Pengembangan Daya Saing Produk dan Bioteknologi Kelautan dan Perikanan, \\ JI. KS Tubun Petamburan VI Slipi Jakarta Pusat Indonesia \\ * Korespondensi Penulis: girirohmadbarokah@gmail.com \\ Diterima: 22 Juli 2016; Disetujui: 14 Oktober 2016
}

\begin{abstract}
ABSTRAK
Telah dilakukan penelitian tentang analisis kelimpahan fitoplankton penyebab HAB (Harmful Algal Bloom) di Perairan Teluk Lampung pada musim barat dan musim timur. Penelitian ini bertujuan untuk mengidentifikasi alga yang berpotensi menyebabkan HAB yang berada di Teluk Lampung dan melihat pola hubungan kelimpahan fitoplankton yang bepotensi menyebabkan HAB dengan nutrien yang terkandung di perairan Teluk Lampung, Kab. Pesawaran, Provinsi Lampung. Pengambilan sampel dilakukan pada musim timur (April) dan musim barat (Oktober) pada tahun 2015. Dari penelitian ini ditemukan bahwa pada musim timur fitoplankton yang teridentifikasi dan berpotensi menyebabkan HAB adalah Amphora sp., Nitzchia sp., Ceratium sp., Dynophisis sp., Gymnodinium sp., dan Nocticulla scintillans. Pada musim barat fitoplankon yang teridentifikasi dan berpotensi menyebabkan HAB adalah Amphora sp., Nitzchia sp., Pseudonitzchia sp., Alexadrium sp., Ceratium sp., Cochlodium polykiroides, Dhynophisis sp., Gambirdiscus toxicus, Gymnodinium sp., Nocticula scintillans, Procentrum sp., Pyrodinium bahamase dan Peridinium sp. Pada musim timur kelimpahan fitoplankton penyebab HAB yang terdapat di perairan Teluk Lampung didominasi oleh spesies Ceratium sp. dengan rata-rata 1,802 ind/L sedangkan pada musim barat kelimpahan fitoplankton di Teluk Lampung didominasi oleh Nitczchia sp., dengan rata-rata kelimpahan 161,207 ind/L.
\end{abstract}

KATAKUNCI : fitoplankton, HAB (harmful algal bloom), kelimpahan, Teluk Lampung

\begin{abstract}
Research on the abundance of phytoplankton causing HAB (Harmful Algal Bloom) in Lampung Bay during west and east monsoon has been carried out. The study aimed to identify the potential algae causing $H A B$ in Lampung Bay and to evaluate the relationship pattern between their abundance and nutrients in the Lampung Bay Waters, District of Pesawaran, Lampung Province. The samples were collected during east monsoon (April) and west monsoon (October) 2015. The results showed that during east monsoon, identified and potential phytoplankton causing $H A B$ were Amphora sp., Nitzchia sp., Ceratium sp., Dynophisis sp., Gymnodinium sp., and Nocticulla scintillans, while for west monsoon were Amphora sp., Nitzchia sp., Pseudonitzchia sp., Alexadrium sp., Ceratium sp., Cochlodium polykiroides, Dhynophisis sp., Gambirdiscus toxicus, Gymnodinium $s p .$, Nocticula scintillans, Procentrum sp., Pyrodinium bahamase, and Peridinium sp. During west monsoon, the phytoplankton was dominated by Ceratium sp. about $1.802 \mathrm{ind} / \mathrm{L}$ in average, while during east monsoon it was dominated by Nitczchia sp. about 161.207 ind/L in average.
\end{abstract}

KEYWORDS: phytoplankton, HAB (harmful algal bloom), abundance, Lampung Bay

\section{PENDAHULUAN}

Selama beberapa dekade terakhir fenomena $\mathrm{HAB}$ ( harmful algal bloom) yang semakin meningkat telah menimbulkan kekhawatiran terhadap negara di seluruh dunia. Fenomena $\mathrm{HAB}$ mendapatkan perhatian karena memiliki dampak negatif terhadap kelangsungan ekosistem pesisir, kegiatan perikanan tangkap, industri budidaya dan bahkan dapat membahayakan kesehatan manusia (Anderson, 2009). Peristiwa HAB juga berdampak negatif terhadap perekonomian dari suatu wilayah karena dapat mengakibatkan kematian pada biota perikanan yang membuat harga biota tersebut menurun bahkan tidak bernilai, meningkatkan 
biaya monitoring terhadap suatu perairan, dan dapat mengganggu aktifitas pariwisata pada perairan tersebut (Hoagland et al., 2006). Peningkatan fenomena $\mathrm{HAB}$ dapat diakibatkan oleh perubahan iklim di laut, meningkatnya kesuburan perairan akibat aktifitas baik industri atau rumah tangga di wilayah pesisir, perubahan pola penyebaran nutrien di perairan akibat masuknya air dari daratan ke badan perairan dalam jumlah yang cukup besar serta fenomena upwelling (Rabalais, Turner, Diaz \& Justic, 2009).

Menurut Mulyani, Widiarti dan Wardhana (2012) peristiwa $\mathrm{HAB}$ dapat dikategorikan menjadi dua, yaitu red tide maker dan toxin producer. Peristiwa $\mathrm{HAB}$ yang masuk dalam kategori red tide makerdisebabkan oleh ledakan populasi fitoplankton berpigmen sehingga warna air laut akan berubah sesuai dengan warna pigmen spesies fitoplanktonnya. Ledakan populasi fitoplankton tersebut dapat menutupi permukaan perairan sehingga selain menyebabkan deplesi oksigen, juga dapat menyebabkan gangguan fungsi mekanik maupun kimiawi pada insang ikan. Hal tersebut dapat mengakibatkan kematian massal ikan. Sedangkan peristiwa HAB yang dikategorikan toxin producer disebabkan oleh metabolit sekunder yang bersifat toksik dari suatu fitoplankton sehingga toksin tersebut dapat terakumulasi pada biota perairan seperti ikan dan kerang.

Global ecology and oceanography of harmful algal blooms (GEOHAB, 2001) menyatakan bahwa toksin yang ditimbulkan akibat alga penghasil toksin dapat diklasifikasikan menjadi diarrhetic shellfish poisoning (DSP), paralytic shellfish poisoning (PSP), neurotoxic shellfish poisoning (NSP), amnesic shellfish poisoning (ASP), dan ciguatera fish poisoning (CFP). ASP disebabkan oleh racun asam domoic yang umumnya dihasilkan oleh Pseudo-nitzschia dari kelompok diatom (Praseno, 2000). NSP terjadi akibat paparan bravetoxin yang terakumulasi dalam tubuh organisme perairan yang umumnya dihasilkan oleh Gymnodinium, Chatonella vernuculosa dan Scrippsiela trochoidea (GEOHAB, 2001). PSP terjadi akibat paparan saxitoxin pada organisme perairan yang dihasilkan oleh genus dinoflagellata Alexandrium, Gymnodinium dan Pyrodinium (Widiarti \& Pratiwi 2003). CFP berasal dari akumulasi toxin pada ikan, terutama yang dihasilkan oleh dinoflagellata genus Gambierdiscus toxicus (Praseno, 1995). DSP disebabkan oleh asam okadoic atau dinophysistoxin yang umumnya disebabkan oleh kelompok alga genus Dinophysis (Mackenzie et al., 2005).

Fenomena $\mathrm{HAB}$ beberapa kali terjadi di perairan Indonesia yang salah satunya di Teluk Hurun Lampung. Menurut Muawanah (2012) kasus blooming alga beberapa kali dilaporkan di perairan Teluk Hurun sejak tahun 2005 sampai 2012, dan kasus terparah terjadi pada musim barat tahun 2012 pada minggu kedua bulan Oktober hingga minggu pertama bulan Desember. Kejadian tersebut mengakibatkan kematian masal ikan termasuk ikan kerapu yang banyak dibudidayakan di keramba jaring apung (KJA) di perairan Teluk Hurun Lampung. Selanjutnya, Muawanah (2012) juga menyatakan bahwa fitoplankton yang telah teridentifikasi menyebabkan blooming di perairan Teluk Hurun Lampung tersebut adalah Cochlodinium sp., Polykrikoides sp., Nocticula scintillans, Pyrodinum bahamase, Phaeocystis sp. dan Dinophisis sp.

Berdasarkan fenomena HAB di perairan Teluk Hurun Lampung yang telah dilaporkan sebelumnya maka perlu dilakukan penelitian untuk mengidentifikasi jenis-jenis fitoplankton beserta kelimpahannya yang berpotensi menyebabkan HAB di perairan tersebut. Selain itu penelitian ini juga bertujuan untuk melihat perbedaan jenis dan kelimpahan fitoplankton penyebab HAB di perairan Teluk Lampung pada musim timur dan musim barat. Hasil penelitian ini diharapkan dapat memberikan informasi dan sebagai early warning system bagi pengelolaan kegiatan perikanan baik tangkap maupun budidaya untuk meningkatkan kualitas dan keamanan produk perikanan yang berasal dari Teluk Lampung sehingga dapat menekan kerugian dari aspek sosial ekonomi maupun kesehatan masyarakat.

\section{BAHAN DAN METODE}

\section{Lokasi PengambilanSampel}

Penelitian kelimpahan fitoplankton penyebab HAB di perairan Teluk Lampung pada musim barat dan musim timur 2015 dilaksanakan di Teluk Hurun Lampung Kab. Pesawaran Provinsi Lampung pada bulan April yang mewakili musim timur dan pada bulan Oktober yang mewakili musim barat. Pengambilan sampel dilakukan dengan cara purposive sampling yaitu pengambilan sampel berdasarkan karakteristik tertentu yang memiliki keterkaitan pada 70 titik di perairan Teluk Lampung yang terbagi menjadi tiga kategori yaitu wilayah sekitar muara sungai, wilayah sekitar badan teluk dan wilayah budidaya KJA (Gambar 1). Sampel yang diambil adalah fitoplankton dan air.

\section{Alat dan Bahan}

Bahan yang digunakan pada penelitian ini adalah sampel air dan sampel fitoplankton yang diambil pada lokasi pengambilan contoh yang telah ditentukan sebelumnya dan larutan lugol $4 \%$ yang digunakan 


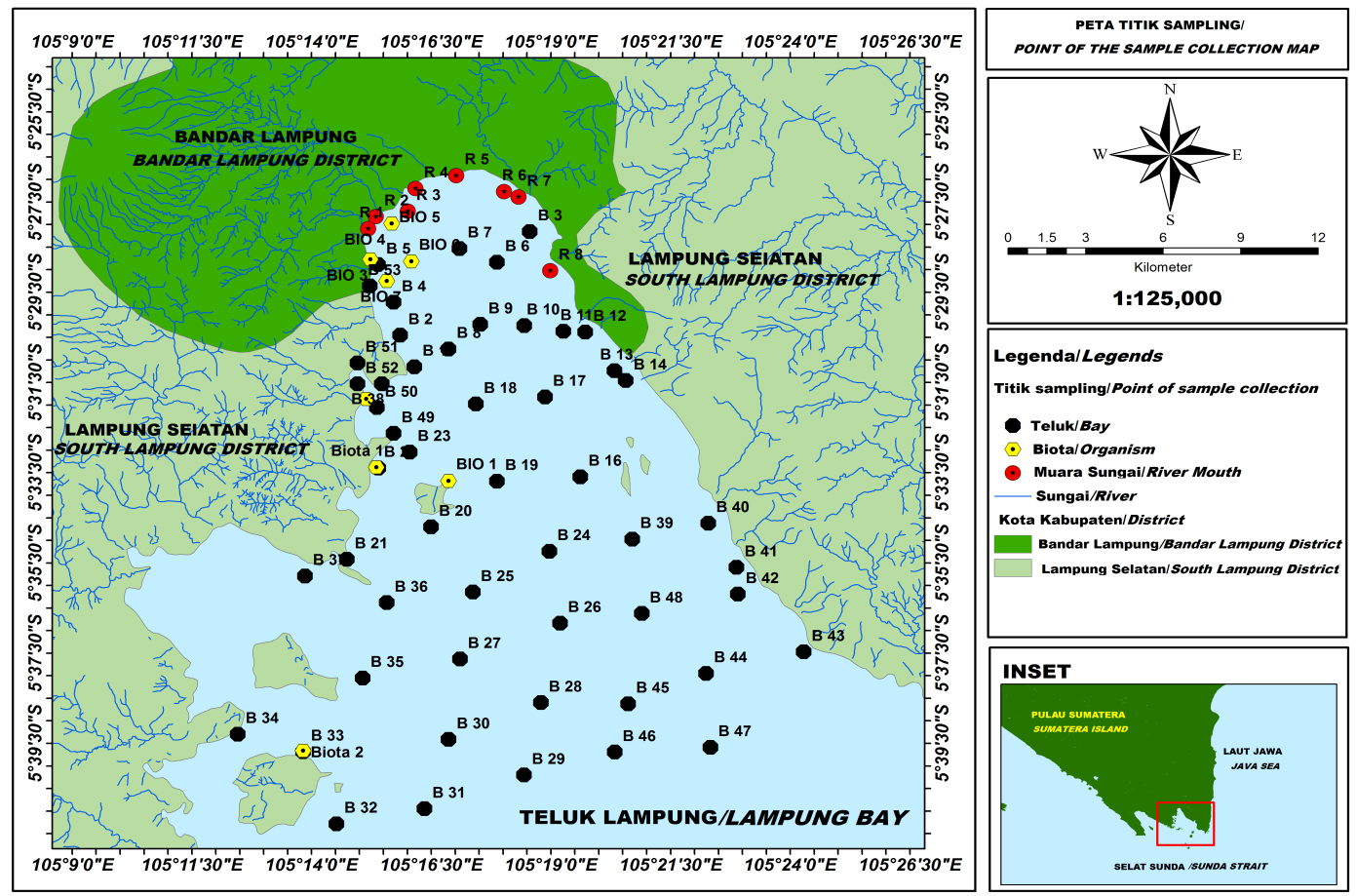

Gambar 1. Lokasi penelitian dan titik pengambilan sampel

Figure 1. Research locations and points of sample collection

sebagai bahan pengawet dan pewarna fitoplankton (Blakar, 1978). Peralatan yang digunakan pada penelitian ini adalah plankton net ukuran $20 \mu \mathrm{m}$ untuk mengambil sampel fitoplankton, water sampler (Nansen) untuk mengambil sampel air, global positioning system (GPS; Garmin type 585) untuk menentukan titik lokasi pengambilan sampel, colorimeter (Hach DR 890) untuk analisa kualitas air (nitrit, nitrat, fosfat dan amonia), botol sampel berbahan plastik poly ethylene (PE) ukuran $1 \mathrm{~L}$ untuk sampel air dan botol sampel PE ukuran $250 \mathrm{~mL}$ untuk sampel fitoplankton, serta mikroskop binokuler untuk analisis dan identifikasi fitoplankton.

\section{Prosedur Pengambilan Sampel dan Analisis}

Sampel fitoplankton (Blakar, 1978) dari setiap titik lokasi pengambilan sampel diambil menggunakan plankton net $30 \mu$ dan ditempatkan pada botol sampel $250 \mathrm{~mL}$ kemudian ditambahkan larutan lugol 4\% untuk mengawetkan dan memberikan pola warna agar mudah untuk dianalisis dan diidentifikasi.

Pengambilan sampel air mengacu pada metode Hutagalung, Setiapermana dan Riyono (1997). Sampel air sebanyak $1 \mathrm{~L}$ diambil dengan menggunakan water sampler (Nansen) pada kedalaman $1 \mathrm{~m}$ di setiap titik lokasi penelitian. Sampel air kemudian ditempatkan pada botol sampel $1 \mathrm{~L}$ dan disimpan pada suhu chilling $4^{\circ} \mathrm{C}$ di dalam cool box. Analisis kualitas air (nitrit, nitrat, fosfat dan amonia) dilakukan dengan menggunakan alat kolorimeter yang mengacu pada prosedur penggunaan alat (Hach, 1999). Identifikasi fitoplankton mengacu pada buku identifikasi fitoplankton (Yamaji, 1996) dan diamati menggunakan mikroskop binokuler. Analisis kelimpahan fitoplankton mengacu pada metode APHA (2005) dengan satuan individu per liter. Rumus perhitungan kelimpahan fitoplankton adalah sebagai berikut :

$\mathrm{N}=\frac{\mathrm{n} \times \text { vol sampel }}{\text { vol diamati } \times \text { vol disaring }} \times 1000$

Keterangan :

$\mathrm{N}$ : kepadatan sel (Ind/liter)

$\mathrm{n}$ : jumlah organisme yang didapat

Kelimpahan fitoplankton kemudian dipetakan pola sebaran horizontalnya menggunakan sofware Geographic Information System (GIS) versi 10.2. Pola hubungan kelimpahan fitoplankton dan nutrien yang berada di perairan Teluk Lampung dianilisis dengan PCA (Principle Component Analysis). Analisis PCA digunakan untuk mengekstraksi informasi esensial yang terdapat dalam suatu matriks data. Output dari analisis ini adalah grafik yang merepresentasikan hubungan antara individu atau antar variabel dari sudut pandang kemiripan (similarity) (Bengen, 2000). 


\section{HASIL DAN PEMBAHASAN}

\section{Fitoplankton Penyebab HAB (Harmful Algal Bloom)}

Hasil penelitian menunjukkan adanya beberapa spesies fitoplankton di perairan Teluk Lampung yang berpotensi menyebabkan HAB yaitu golongan toxin producerdan red tide maker. Pada musim timur (April), fitoplankton yang teridentifikasi dan berpotensi menyebabkan HAB adalah Amphora sp., Nitzchia sp., Ceratium sp., Dynophisis sp., Gymnodinium sp., dan Nocticulla scintillans. Sedangkan pada musim barat (bulan Oktober), adalah Amphora sp., Nitzchia sp.,
Pseudonitzchia sp., Alexadrium sp., Ceratium sp., Cochlodium polykiroides, Dhynophisis sp., Gambirdiscus toxicus, Gymnodinium sp., Nocticula scintillans, Procentrum sp., Pyrodinium bahamase, dan Perinidium sp. Kelimpahan fitoplankton penyebab HAB pada musim timur dan barat dapat dilihat pada Gambar 2 dan Gambar 3 sedangkan pengelompokan dan potensi dampak fitoplankton penyebab HAB yang ditemukan di lokasi penelitian dapat dilihat pada Tabel 1. Berdasarkan hasil penelitian dan mengacu pada GEOHAB (2001), Widiarti dan Pratiwi (2003) serta Smadya dan Reynold (2001) tentang pengelompokan jenis fitoplankton berdasarkan dampak yang dapat ditimbulkan, fitoplankton yang ditemukan pada musim

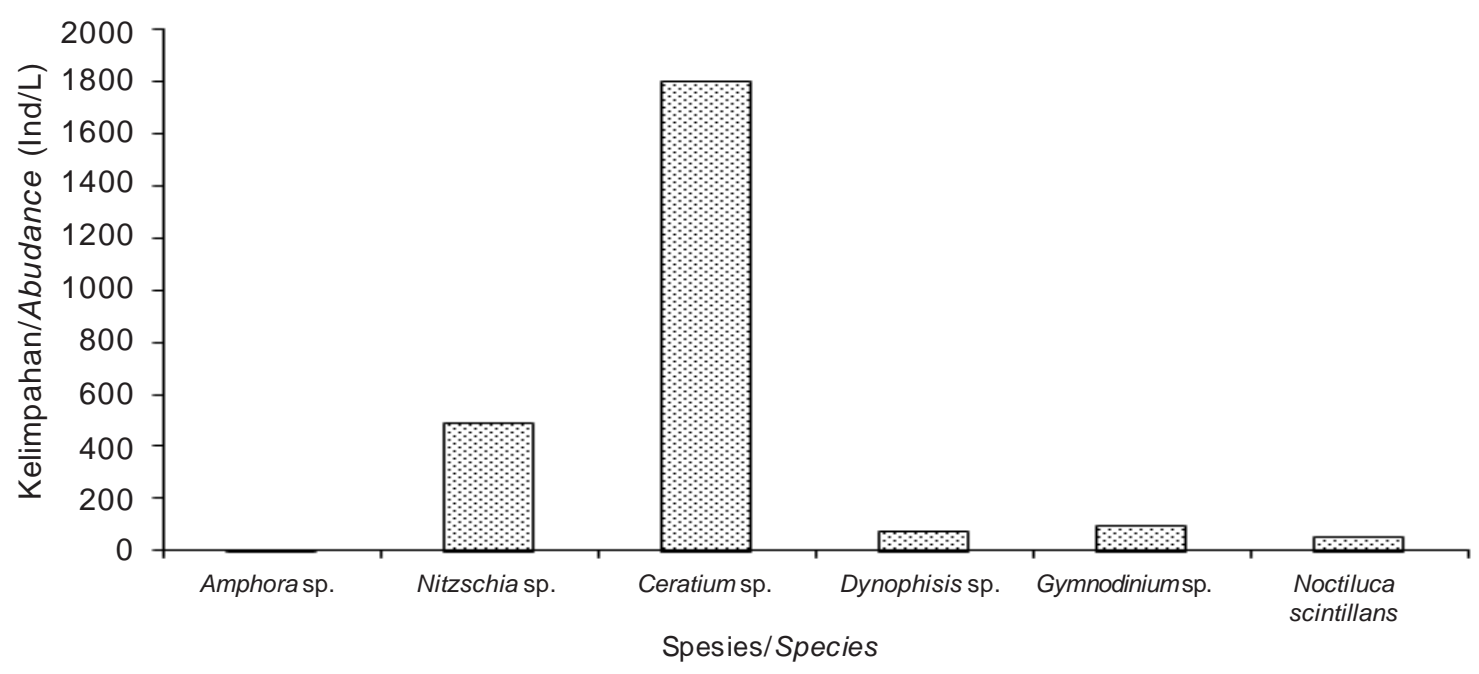

Gambar 2. Kelimpahan fitoplankton penyebab HAB pada musim timur (April) di perairan Teluk Lampung Figure 2. The abundance of phytoplankton causing HAB in Lampung Bay during east monsoon (April)

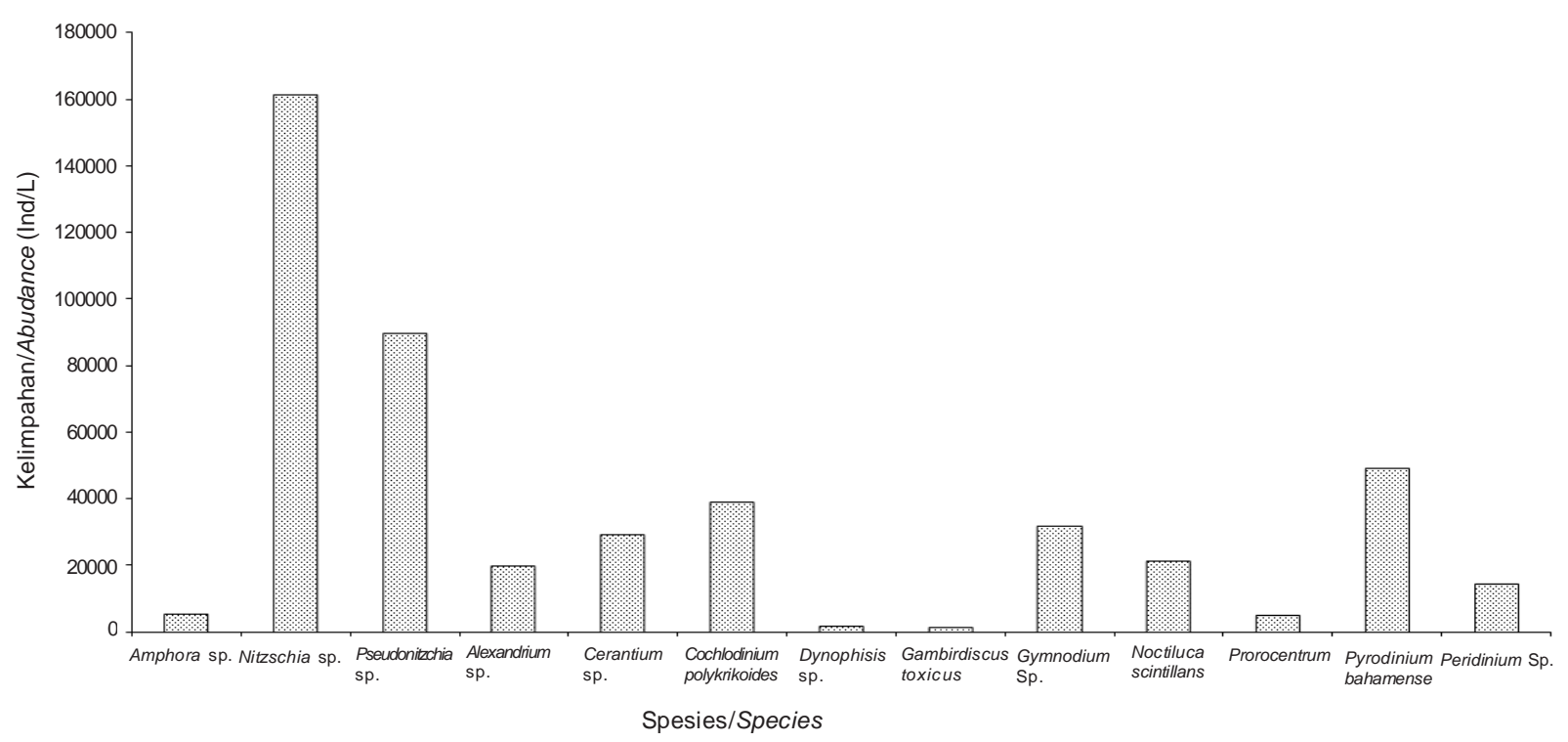

Gambar 3. Kelimpahan fitoplankton penyebab HAB pada musim barat (Oktober) di perairan Teluk Lampung Figure 3. The abundance of phytoplankton causing HAB in Lampung Bay during west monsoon (October) 
timur dan masuk kelompok red tide maker adalah Amphora sp., Noctiluca scintilans dan Ceratium sp. Sedangkan fitoplankton red tide maker yang ditemukan pada musim barat adalah Amphora sp., Noctiluca scintilans, Ceratium sp., Procentrum sp. dan Pyrodinium bahamase. Fitoplankton golongan toxin producer yang ditemukan pada musim timur adalah Nitzchia sp., Dynophisis sp. dan Gymnodinium sp., sedangkan fitoplankton golongan toxin producer yang ditemukan pada musim barat adalah
Nitzchia sp., Dynophisis sp., Gymnodinium sp., Pseudonitzchia sp., Gamberdicus toxicus, Cochlodinium polykrikoides dan Piridinium sp.

Dibandingkan dengan musim timur, fitoplankton yang ditemukan pada musim barat lebih beragam jenisnya, dan kelimpahan fitoplankton yang ditemukan pada musim barat juga lebih tinggi dibandingkan dengan pada musim timur. Hal ini diduga disebabkan intensitas hujan yang lebih tinggi pada saat pengambilan sampel di musim timur, sedangkan pada

Tabel 1. Pengelompokan dan potensi dampak fitoplankton penyebab HAB yang ditemukan di perairan Teluk Lampung

Table 1. Grouping and potential impact of the phytoplankton causing HAB found in Lampung Bay

\begin{tabular}{|c|c|c|c|c|c|}
\hline $\begin{array}{l}\text { Spesies/ } \\
\text { Species }\end{array}$ & $\begin{array}{l}\text { Kelompok/ } \\
\text { Group 1) }\end{array}$ & $\begin{array}{l}\text { Potensi Dampak/ } \\
\text { Potensial Impact }{ }^{2)}\end{array}$ & $\begin{array}{l}\text { Musim } \\
\text { Timur/ } \\
\text { East } \\
\text { Monsoon }\end{array}$ & $\begin{array}{c}\text { Musim } \\
\text { Barat/ } \\
\text { West } \\
\text { Monsoon }\end{array}$ & Pustaka/References \\
\hline Amphora & \multirow{5}{*}{$\begin{array}{c}\text { Penyebab } \\
\text { pasang } \\
\text { merah/ } \\
\text { Red tide } \\
\text { maker }\end{array}$} & \multirow{5}{*}{$\begin{array}{l}\text { penurunan kadar } \\
\text { oksigen pada perairan, } \\
\text { mereduksi kualitas } \\
\text { perairan dan kematian } \\
\text { masal pada biota } \\
\text { perairan / declining } \\
\text { oxygen levels in } \\
\text { waters, reducing waters } \\
\text { quality, massive } \\
\text { mortality of biota }\end{array}$} & + & + & Smadya\& Reynold (2001) \\
\hline $\begin{array}{l}\text { Noctiluca } \\
\text { scintilans }\end{array}$ & & & + & + & $\begin{array}{l}\text { GEOHAB (2001), Widiarti \& Pratiw i } \\
\text { (2003), Smadya \& Reynold (2001) }\end{array}$ \\
\hline Procentrum & & & - & + & $\begin{array}{l}\text { GEOHAB (2001), Smadya \& Reynold } \\
\text { (2001), Widiarti \& Pratiw i (2003) }\end{array}$ \\
\hline $\begin{array}{l}\text { Pyrodinium } \\
\text { bahamase }\end{array}$ & & & - & + & Smadya \& Reynold (2001), \\
\hline Ceratium & & & + & + & GEOHAB (2001), \\
\hline Nitzchia & & $\begin{array}{l}\text { amnestic shelfish } \\
\text { poisoning (ASP) }\end{array}$ & + & + & GEOHAB (2001) \\
\hline Dynophisis & & $\begin{array}{l}\text { diarhetic shelfish } \\
\text { poisoning (DSP) }\end{array}$ & + & + & $\begin{array}{l}\text { GEOHAB (2001), Smadya \& Reynold } \\
\text { (2001), Widiarti \& Pratiw i (2003) }\end{array}$ \\
\hline Gymnodinium & & $\begin{array}{l}\text { Paralytic Shelfish } \\
\text { Poisioning (PSP) }\end{array}$ & + & + & GEOHAB (2001),Widiarti \& Pratiw i (2003) \\
\hline Pseudo-niczchia & $\begin{array}{l}\text { Penghasil } \\
\text { toksin/ }\end{array}$ & $\begin{array}{l}\text { Amnestic Shelfish } \\
\text { Poisoning (ASP) }\end{array}$ & - & + & $\begin{array}{l}\text { GEOHAB (2001), Widiarti \& Pratiw i } \\
(2003)\end{array}$ \\
\hline Alexandrium & $\begin{array}{l}\text { Toxin } \\
\text { producer }\end{array}$ & $\begin{array}{l}\text { Paralytic Shelfish } \\
\text { Poisioning (PSP) }\end{array}$ & - & + & $\begin{array}{l}\text { GEOHAB (2001), Widiarti \& Pratiw i } \\
\text { (2003), Smadya \& Reynolds (2001) }\end{array}$ \\
\hline $\begin{array}{l}\text { Gamberdicus } \\
\text { toxicus }\end{array}$ & & $\begin{array}{l}\text { Ciguatera Fish } \\
\text { Poisoning (CFP) }\end{array}$ & - & + & GEOHAB (2001),Widiarti \& Pratiw i (2003) \\
\hline $\begin{array}{l}\text { Cochlodinium } \\
\text { polykrikoides }\end{array}$ & & $\begin{array}{l}\text { Paralytic Shelfish } \\
\text { Poisioning (PSP) }\end{array}$ & - & + & Smadya \& Reynold (2001) \\
\hline Peridinium & & $\begin{array}{c}\text { Paralytic Shelfish } \\
\text { Poisioning (PSP) }\end{array}$ & - & + & Smadya \& Reynold (2001) \\
\hline
\end{tabular}

Keterangan :

+ : fitoplankton ditemukan/Phytoplankton found

- : fitoplankton tidak ditemukan/No phytoplankton found

1): Pengelompokan fitoplankton berdasarkan literatur/ Phytoplankton grouping based on reference

2): Pengelompokan potensi dampak fitoplankton berdasarkan literatur/The grouping of phytoplnkton potential impact based on reference 


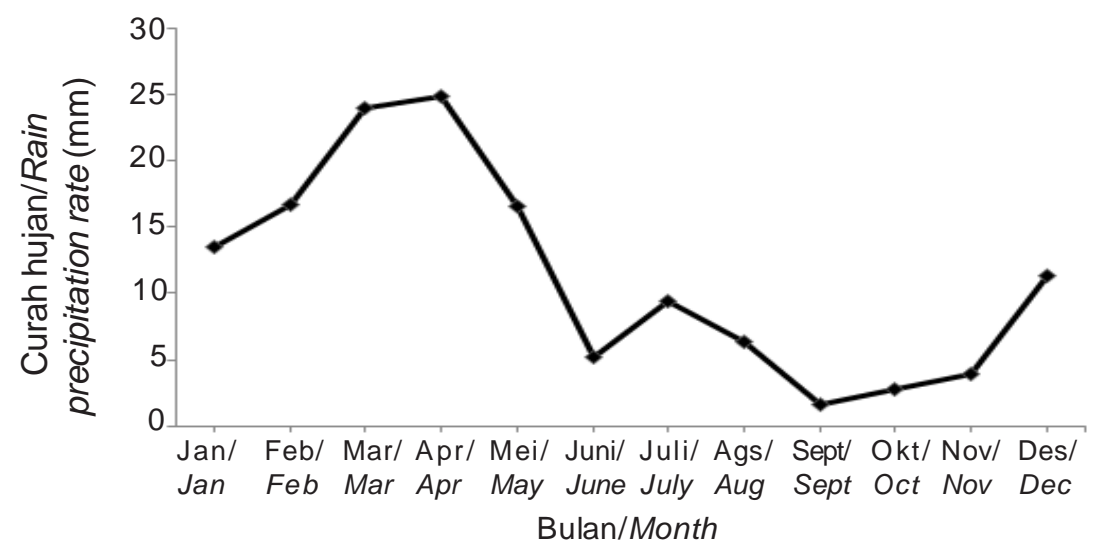

Gambar 4.Profil curah hujan rata-rata per bulan di Provinsi Lampung tahun 2015 (BMKG, 2016)

Figure 4. Rainfall profile of Lampung Province in 2015 (BMKG, 2016)

saat pengambilan sampel di musim barat intensitas hujan relatif rendah dan memasuki peralihan ke musim penghujan (Gambar 4). Menurut Krismono dan Sugianti (2007) konsentrasi nutrien pada musim penghujan akan lebih rendah dibandingkan dengan musim kemarau. Hal ini menyebabkan kelimpahan fitoplankton pada musim penghujan relatif lebih rendah. Kondisi ini disebabkan karena pada musim penghujan salinitas, suhu dan penitrasi cahaya yang masuk ke perairan menjadi rendah. Selain itu tingkat kekeruhan perairan pada musim penghujan juga lebih tinggi dibandingkan musim kemarau karena pengaruh sedimen yang terbawa dari aliran sungai yang masuk ke badan perairan. Akibatnya kelimpahan fitoplankton pada musim penghujan relatif lebih rendah.

\section{Kondisi Nutrien Perairan Teluk Lampung}

Nutrien yang dianalisis pada penelitian ini meliputi kadar nitrit, nitrat, amonia dan fosfat. Perbandingan kadar nutrien di perairan Teluk Lampung pada musim barat dan musim timur dapat dilihat pada Gambar 5 . Analisis kadar nutrien yang terkandung di perairan Teluk Lampung dilakukan untuk melihat pengaruh kadar nutrien terhadap kelimpahan fitoplankon penyebab HAB.

Rata-rata kadar nitrit $(0,14 \mathrm{mg} / \mathrm{L})$ dan kadar nitrat $(0,706 \mathrm{mg} / \mathrm{L})$ pada seluruh stasiun sampling di musim timur lebih tinggi dibandingkan rata-rata kadar nitrit $(0,12 \mathrm{Mg} / \mathrm{L})$ dan kadar nitrat $(0,587 \mathrm{mg} / \mathrm{L})$ pada musim barat. Sedangkan rata-rata kadar amonia $(0,15 \mathrm{mg} / \mathrm{L})$ dan phospat $(0,185 \mathrm{mg} / \mathrm{L})$ pada musim barat lebih tinggi dibandingkan rata-rata kadar amonia $(0,14 \mathrm{Mg} /$ L) dan kadar phospat $(0,052 \mathrm{mg} / \mathrm{L})$ pada musim timur.

Menurut Koropitan, Hadi, Radjawane dan Damar (2004) tingginya kadar nitrit, nitrat dan amonia pada suatu perairan dapat diakibatkan oleh banyaknya bahan organik yang masuk ke badan perairan akibat kegiatan budidaya KJA di Teluk Lampung, terutama

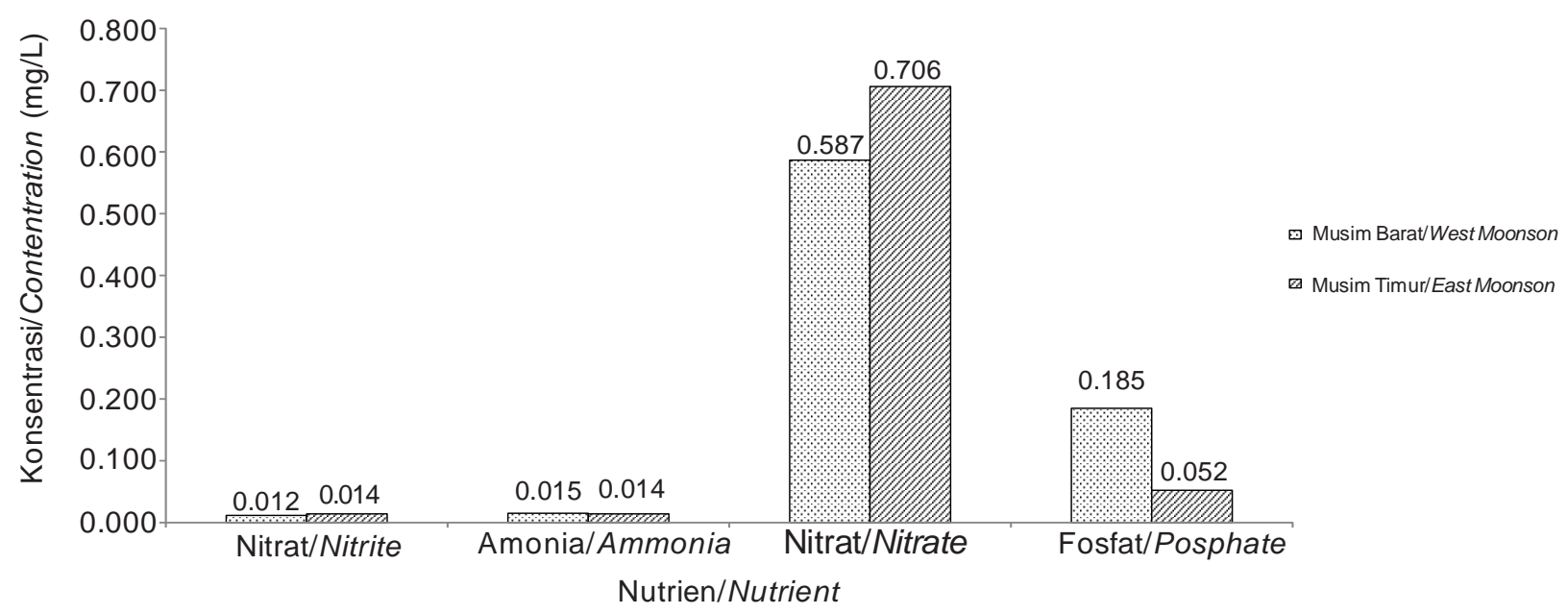

Gambar 5. Konsentrasi nutrien di perairan Teluk Lampung pada musim barat dan musim timur Figure 5. Nutrient concentration of Lampung Bay in west and east monsoon 
budidaya kerapu dan kakap. Sedangkan tingginya kadar fosfat diakibatkan oleh banyaknya aliran limbah yang mengandung fosfat yang mengalir ke sungai yang berasal dari kegiatan masyarakat sekitar dan bermuara di Teluk Lampung. Yuliana (2012) menyatakan bahwa konsentrasi nitrat yang lebih dari $0,2 \mathrm{mg} / \mathrm{L}$ menandakan bahwa wilayah perairan tersebut memiliki tingkat kesuburan yang tinggi. Sedangkan menurut Hasani, Adiwilaga dan Pratiwi (2012) konsentrasi fosfat pada perairan yang lebih dari 0,1 $\mathrm{mg} / \mathrm{L}$ menunjukkan bahwa perairan tersebut mengalami eutrofikasi. Menurut Kartamihardja dan Krismono (2003) kelimpahan fitoplankton berkaitan erat dengan kandungan nitrat dan fosfat perairan. Sedangkan menurut Nontji (2006), nitrat dan fosfat perairan merupakan unsur pembatas pertumbuhan
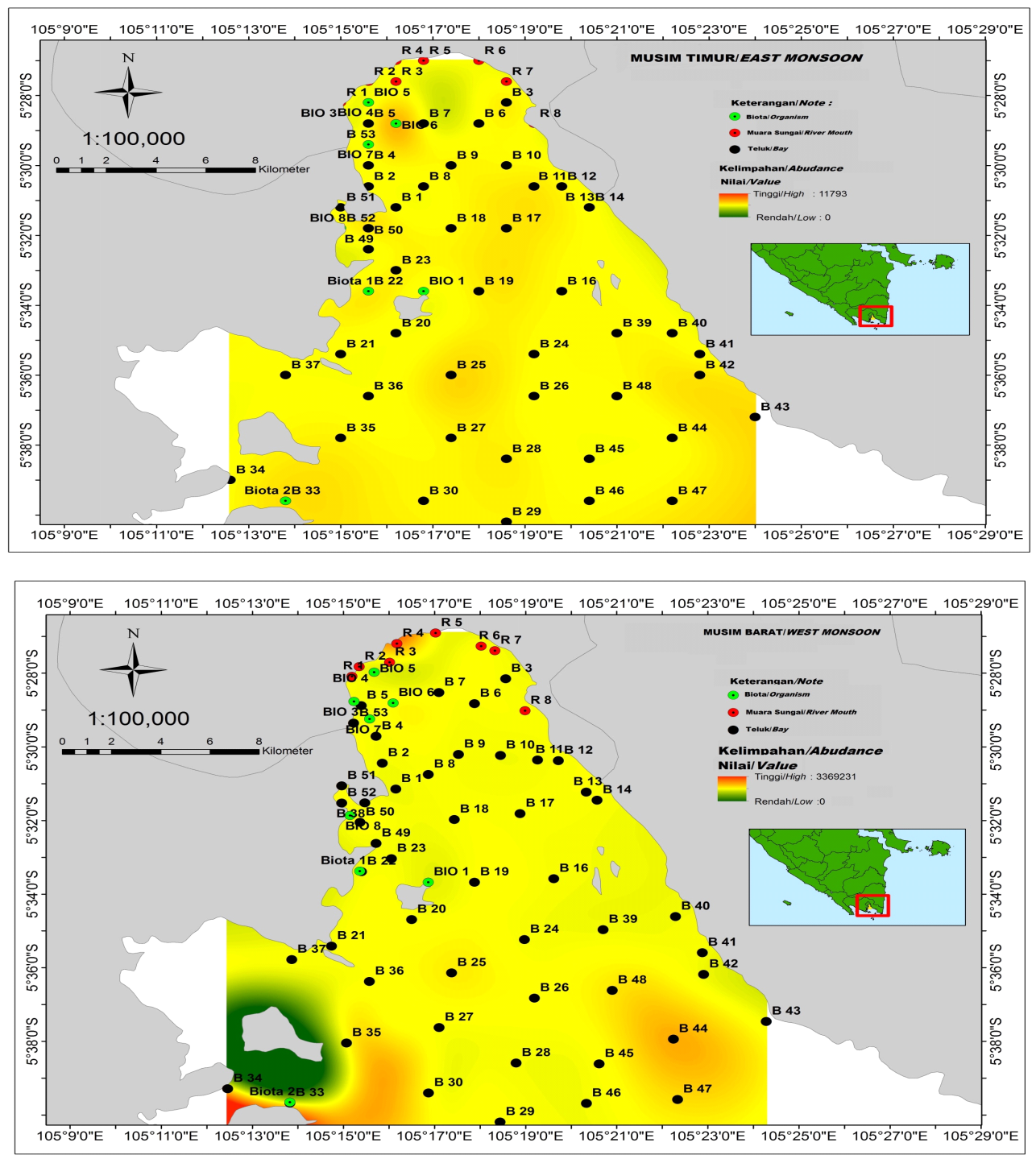

Keterangan/Note:

$\mathrm{R}$ = titik sampling di wilayah muara sungai/point of the sample collection in the river mouth

$\mathrm{B}=$ titik sampling di wilayah teluk/point of the sample collection in the bay

$\mathrm{BIO}=$ titik sampling biota budidaya/point of the sample collection in aquaculture biota

Angka dibelakang huruf $\mathrm{R}, \mathrm{B}, \mathrm{BIO}$ menunjukkan stasiun pengambilan sampel/The number behind $R, B, B I O$, showing station of the sample collection

Gambar 6. Sebaran spasial kelimpahan total fitoplankton penyebab HAB pada musim timur (A) dan musim barat (B) di perairan Teluk Lampung

Figure 6. Spatial distribution of phytoplankton causing HAB in east $(A)$ and west monsoon $(B)$ in Lampung Bay 
fitoplankton karena keberadaannya diperlukan untuk mempertahankan fungsi membran sel dan silika dalam pembentukan dinding sel fitoplankton.

\section{Sebaran Spasial Fitoplankton Penyebab Harmful Algal Bloom (HAB)}

Peta sebaran kelimpahan total fitoplankton penyebab HAB pada musim barat dan musim timur di perairan Teluk Lampung ditunjukkan oleh Gambar 6. Peta tersebut menunjukkan sebaran kelimpahan fitoplankton pada setiap stasiun pengambilan sampel baik di area muara sungai, area budidaya maupun area teluk.

Sebaran spasial kelimpahan fitoplankton pada musim timur di perairan teluk Lampung (Gambar 6A) menunjukkan bahwa sebaran kelimpahan tertinggi terdapat pada stasiun pengambilan sampel di wilayah budidaya dan wilayah teluk yang mendekati laut lepas. Sedangkan sebaran spasial kelimpahan pada musim barat di perairan Teluk Lampung (Gambar 6B) menunjukkan sebaran kelimpahan tertinggi terdapat pada daerah sekitar aliran sungai dan wilayah teluk yang telah mendekati laut lepas. Sebaran kelimpahan fitoplankton pada musim barat dan musim timur yang terdapat pada Gambar 6 cenderung memilki pola sebaran warna yang hampir sama, akan tetapi pada musim barat kelimpahan total fitoplankton penyebab HAB lebih tinggi dibandingkan dengan musim timur.

Kelimpahan fitoplankton yang tinggi pada area budidaya baik pada musim barat dan musim timur kemungkinan disebabkan oleh banyaknya nutrisi yang terkandung pada area perairan tersebut akibat limbah pakan budidaya KJA yang banyak mengandung nitrit, nitrat dan amonia. Susana (2000) menyatakan bahwa terdapat 50 unit KJA dengan biomassa ikan sekitar $500 \mathrm{~kg}$ yang tersebar di sekitar Teluk Lampung. Menurut Zhou et al. (2011), kegiatan budidaya KJA yang dilakukan secara intensif menyebabkan akumulasi nitrogen dan fosfat yang berasal dari sisa pakan yang menyebabkan peningkatan nutrisi di perairan. Tingginya kelimpahan fitoplankton di daerah sekitar muara sungai pada musim barat dimungkinkan karena perubahan massa air yang terdapat pada muara sungai akibat kondisi cuaca. Selain itu banyaknya unsur hara dari daratan baik yang berasal dari limbah pertanian, rumah tangga maupun industri yang terbawa lewat aliran sungai dan bermuara di perairan teluk lampung juga mempengaruhi kelimpahan dan sebaran distribusi fitoplankton penyebab HAB. Sebaran kelimpahan fitoplankton pada area teluk dimungkinkan banyak dipengaruhi oleh tingkat kecerahan, oksigen terlarut dan salinitas di area teluk, karena semakin jauh lokasi sampling dari daratan semakin tinggi tingkat kecerahan dan salinitasnya. Menurut Simanjuntak (2012) pola sebaran kelimpahan tersebut dipengaruhi oleh beberapa parameter seperti nutrien, salinitas, kecerahan, $\mathrm{pH}$, suhu dan kualitas lingkungan perairan.

\section{Pola Hubungan Fitoplankton Penyebab HAB dan Nutrien di Teluk Lampung}

Analisis pola hubungan kelimpahan fitoplankton penyebab HAB pada musim timur di perairan Teluk Lampung ditunjukkan pada Tabel 2. Berdasarkan analisis korelasi Spearman, terdapat hubungan yang terbalik $(R=-0,251)$ antara kelimpahan fitoplankton dengan kadar amonia $(p<0,05)$ diperairan teluk Lampung pada musim timur. Berdasarkan hal tersebut dapat dinyatakan bahwa semakin tinggi kadar amonia maka kelimpahan fitoplankton semakin rendah. Hubungan korelasi negatif yang lain ditunjukkan oleh

Tabel 2. Matriks korelasi kelimpahan fitoplankton penyebab HAB pada musim timur dengan nutrien di perairan Teluk Lampung

Table 2. Corellation matrix between the abundance of phytoplankton causing $H A B$ and nutrient content during east monsoon in Lampung Bay

\begin{tabular}{|c|c|c|c|c|c|}
\hline Variabel/Variable & $\begin{array}{c}\text { Ke limpahan Fitoplankton/ } \\
\text { Abundance of } \\
\text { Phytoplankton }\end{array}$ & $\begin{array}{l}\text { Nitrit/ } \\
\text { Nitrite } \\
(\mathrm{mg} / \mathrm{L})\end{array}$ & $\begin{array}{c}\text { Amonia/ } \\
\text { Am monia } \\
\text { (m g/L) }\end{array}$ & $\begin{array}{l}\text { Nitrat/ } \\
\text { Nitrate } \\
(\mathrm{mg} / \mathrm{L})\end{array}$ & $\begin{array}{c}\text { Fosfat/ } \\
\text { Phospate } \\
(\mathrm{mg} / \mathrm{L})\end{array}$ \\
\hline Nitrit/Nitrite $(\mathrm{m} \mathrm{g} / \mathrm{L})$ & 0.004 & 1 & 0.133 & 0.148 & -0.053 \\
\hline Nitrat/Nitrate $(\mathrm{mg} / \mathrm{L})$ & 0.014 & 0.148 & 0.239 & 1 & 0.479 \\
\hline Fospat/Phospate (m g/L) & -0.036 & -0.053 & 0.394 & 0.479 & 1 \\
\hline
\end{tabular}


Tabel 3. Matriks korelasi kelimpahan fitoplankton penyebab HAB pada musim barat dengan nutrien di perairan Teluk Lampung

Table 3. Corellation matrix between the abundance of phytoplankton causing HAB and the nutrient content during west monsoon in Lampung Bay

\begin{tabular}{lccccc}
\hline \multicolumn{1}{c}{ Variabel/Variable } & $\begin{array}{c}\text { Kelimpahan } \\
\text { Fitoplankton/ } \\
\text { Abundance of } \\
\text { Phytoplankton }\end{array}$ & $\begin{array}{c}\text { Nitrit/Nitrite } \\
(\mathbf{m g} / \mathbf{L})\end{array}$ & $\begin{array}{c}\text { Amonia/ } \\
\text { Ammonia } \\
(\mathbf{m g} / \mathbf{L})\end{array}$ & $\begin{array}{c}\text { Nitrat/Nitrate } \\
(\mathbf{m g} / \mathbf{L})\end{array}$ & $\begin{array}{c}\text { Fosfat/Phospate } \\
(\mathbf{m g} / \mathbf{L})\end{array}$ \\
\hline $\begin{array}{l}\text { Kelimpahan Fitoplankton/ } \\
\text { Abundance of Phytoplankton }\end{array}$ & 1 & -0.156 & 0.067 & -0.155 & 0.083 \\
Nitrit/Nitrite (mg/L) & -0.156 & 1 & 0.166 & 0.339 & 0.226 \\
Amonia/Ammonia (mg/L) & -0.067 & 0.166 & 1 & 0.23 & 0.16 \\
Nitrat/Nitrate (mg/L) & -0.155 & 0.339 & 0.23 & 1 & 0.162 \\
Fosfat/Phospate (mg/L) & -0.083 & 0.226 & 0.16 & 0.162 & 1 \\
\hline
\end{tabular}

kelimpahan fitoplankton dengan kadar fosfat $(R=-0,036)$ tetapi hubungan ini tidak signifikan $(p>0,05)$. Sedangkan pola hubungan yang berkorelasi positif ditunjukkan oleh oleh kelimpahan fitoplankton penyebab HAB pada musim timur dengan kadar nitrit $(0,004)$ dan nitrat $(0,014)$, meskipun terdapat korelasi yang positif antara kelimpahan fitoplankton dengan kadar nitrit dan nitrat tetapi secara statistik hubungan ini tidak signifikan ( $p>0,05)$. Menurut Effendi (2003) amonia dalam perairan akan didegradasi menjadi nitrit dan kemudian menjadi nitrat melalui proses nitrifikasi sehingga penurunan amonia dalam perairan akan meningkatkan kadar nitrit dan nitrat dalam perairan tersebut. Berdasarkan Gambar 7(A) secara deskriptif kelimpahan fitoplankton pada musim timur memiliki kedekatan hubungan dengan nitrit dan nitrat perairan. Hal ini menunjukkan bahwa kenaikan kelimpahan fitoplankton penyebab $\mathrm{HAB}$ pada musim timur di
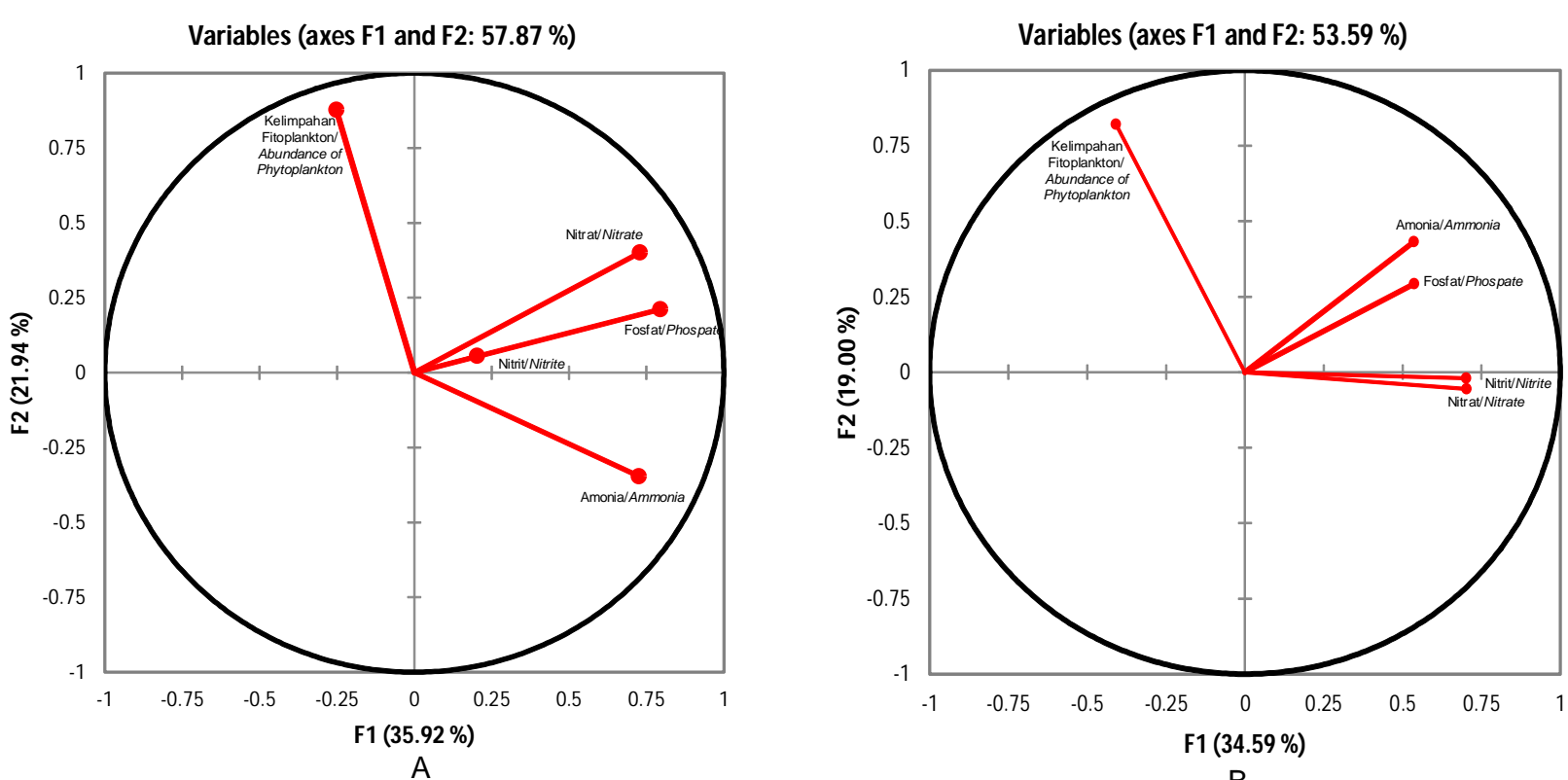

Gambar 7. Analisis komponen utama kelimpahan fitoplankton penyebab HAB dengan nutrien pada musim timur (A) dan pada musim barat (B) di perairan Teluk Lampung.

Figure 7. Main component analysis between the abundance of phytoplankton causing $H A B$ and the nutrient content during east monsoon (A) and west monsoon (B) in Lampung Bay 
perairan Teluk Lampung kemungkinan disebabkan oleh naiknya kadar nitrat dan nitrit serta penurunan kadar amonia dan fosfat pada perairan tersebut. Effendi (2003) menyatakan bahwa nutrien nitrat dan nitrit merupakan sumber makanan yang penting bagi pertumbuhan fitoplankton. Korelasi negatif pada nutrien fosfat dan amonia terhadap kelimpahan fitoplankton penyebab HAB pada musim timur di perairan Teluk Lampung bukan berarti menunjukkan kedua nutrien tersebut tidak berperan terhadap kelimpahan fitoplankton akan tetapi mungkin dikarenakan variabilitas kedua nutrien tersebut pada musim timur serta jumlah sampelnya tidak mencukupi sehingga korelasinya tidak cukup jelas (Soedibjo, 2007).

Analisis pola hubungan kelimpahan fitoplankton penyebab HAB pada musim barat dengan nutrien perairan Teluk Lampung ditunjukkan dalam Tabel 3. Berdasarkan analisis korelasi Spearman, terdapat hubungan yang terbalik dan signifikan $(p<0,05)$ antara kelimpahan fitoplankton dengan kadar nitrit $(R=-0,156)$ dan nitrat $(R=-0,155)$. Hal tersebut menunjukkan bahwa penurunan nitrit dan nitrat akan meningkatkan kelimpahan fitoplankton pada musim barat di perairan Teluk Lampung, sedangkan pola hubungan yang berkorelasi positif ditunjukkan oleh kelimpahan fitoplankton dengan amonia $(R=0.067)$ dan fosfat $(R=0,083)$, akan tetapi secara statistik hubungan ini tidak signifikan ( $p>0,05)$. Berdasarkan Gambar 7(B) terlihat hubungan deskriptif antara kelimpahan fitoplankton pada musim barat memiliki kedekatan dengan amonia dan fosfat dibandingkan dengan nitrat dan nitrit. Hal tersebut menunjukkan bahwa pertumbuhan kelimpahan fitoplankton penyebab HAB pada musim barat diikuti dengan meningkatnya konsentrasi amonia dan fosfat di perairan Teluk Lampung. Pola hubungan ini berbeda dengan apa yang ditemukan pada musim timur yaitu perubahan kelimpahan fitoplankton penyebab HAB pada musim timur berkorelasi positif dengan nutrien nitrit dan nitrat namun berkorelasi negatif dengan amonia dan fosfat. Amonia dan fosfat di perairan Teluk Lampung kemungkinan berasal dari limbah rumah tangga yang masuk ke badan teluk lewat aliran sungai serta akibat aktifitas perikanan budidaya KJA di perairan tersebut. $\mathrm{Hal}$ ini sesuai dengan pernyataan Santoso (2006) yang menyatakan bahwa tingginya senyawa amonia dan fosfat pada perairan disebabkan oleh kegiatan budidaya perikanan di perairan tersebut serta limpasan air sungai dari kegiatan pertambakan dan pertanian.

\section{KESIMPULAN}

Hasil identifikasi jenis dan kelimpahan fitoplankton penyebab HAB di perairan Teluk Lampung menunjukkan bahwa terdapat perbedaan spesies dan kelimpahan fitoplankton pada kedua musim tersebut. Spesies dan kelimpahan fitoplankton penyebab HAB yang ditemukan pada musim barat lebih tinggi dibandingkan dengan musim timur. Selain itu distribusi spasial fitoplankton penyebab HAB di perairan teluk Lampung pada musim barat dan musim timur terkonsentrasi pada area budidaya KJA dan muara sungai sehingga early warning system terkait dengan dampak blooming fitoplankton HAB perlu diterapkan pada kedua lokasi tersebut.

\section{DAFTAR PUSTAKA}

APHA, (2005). Standard Method for the Examination water and Wastewater. (15 th Edition). American Public Health Association, Washington, D.C., pp. 1134.

Anderson, D.M.(2009). Approaches to monitoring, control and management of harmful algal blooms (HABs). Ocean Coastal Management, 52 (7), 342-347.

BMKG. (2016). Data online curah hujan. Retrieved from http://www.dataonline.bmkg.go.id/dataiklim

Bengen, D.G. (2000). Pengenalan dan Pengelolaan Ekosistem Mangrove. Pusat Kajian Sumberdaya Pesisir dan Lautan (PKSPL) IPB. Bogor.

Blakar, I.A. (1978). A Simple Water and Plankton Sampler. Freshwater Biology, 8(6), 533-537.

Effendi, H. (2003). Telaah Kualitas Air Bagi Pengelolaan Sumber Daya dan Lingkungan Perairan. Kanisius, Yogyakarta, pp. 151.

GEOHAB (2001). Global ecology and oceanography of harmful algae blooms: Science Plan. Gilbert, P., and G. Pitcher (eds.). SCOR and IOC, Baltimore and Paris, pp.86.

Hach. (1999). Datalogging Colorimeter Handbook. Hach Company, P.O. Box 608, Loveland, Co.pp. 608.

Hasani, Q., Adiwilaga, E.M., \& Pratiwi, N.T.M. (2012). The relationship between the harmful algal blooms (habs) phenomenon withnutrients at shrimp farms and fish cage culture sites in pesawaran district Lampung Bay. Makara Journal of Science, 16(3), 183-191.

Hoagland, P., Jin, D., Beet, A., Kirkpatrick, B., Reich, A., Ullmann, S., Fleming, L.E., \& Kirkpatrick, G. (2014). The human health effects of Florida Red Tide (FRT) blooms: an expanded analysis. Environmental International, 68, 144-153.

Hutagalung, H.P., Setiapermana, D., \& Riyono, S.H. (1997). Metode Analisis Air Laut, Sedimen dan Biota. Buku 2. Puslitbang Oseanologi, LIPI, Jakarta, pp. 182.

Kartamihardja, E.S., \&Krismono, A.S.N. (2003). Distribusi Spasial Temporal Kelimpahan Dan Biomassa Fitoplankton Dalam Kaitannya Dengan Potensi Produksi Ikan Di Waduk IR.H. Djuanda, Jawa Barat. Jurnal Penelitian Perikanan Indonesia, 9 (7), 9-18.

Koropitan, A.F, Hadi, S., Radjawane, I.M., \& Damar, A.(2004). Study Dinamika Ekosistem Perairan di 
Teluk Lampung : Permodelan Gabungan Hidrodinamika-Ekosistem. Jurnal IImu-IImu Perikanan dan Perikanan Indonesia, 11(1), 29-38.

Krismono \& Sugianti Y. (2007). Distribusi Plankton di Waduk Kedungombo Plankton Distribution in Kedungombo Reservoir. Jurnal Perikanan,6(2), 108115.

MacKenzie, A.L., Beuzenberg, V., Holland, P.T., McNabb, P, Suzuki, T., \& Selwood, A.(2005). Pectenotoxin and okadaic acid-based toxin profiles in Dinophysis acuta and Dinophysis acuminata from New Zealand. Harmful Algae, 4(3), 75-85.

Muawanah. (2012). Pasang Merah Muncul di Teluk Lampung. Koran Lampung Post. 25 Oktober 2012.

Mulyani, R., Widiarti, \& Wardhana W. (2012). Sebaran Spasial Spesies Penyebab Harmful Algal Bloom (HAB) di Lokasi Budidaya Kerang Hljau (Perna viridis) Kamal Muara, Jakarta Utara pada Bulan Mei 2011. Jurnal Akuatika, 3(1), 28-39.

Nontji, A.(2006). Plankton Laut. Lembaga IImu Pengetahuan Indonesia. Pusat Penelitian Oseanografi, Jakarta, p. 42.

Praseno, D.P. (1995). A study on HAB organism in Indonesian waters. Proceedings of the International seminar on marine fisheries environment. EMDEC \& JICA, 119-125.

Praseno, D.P. (2000). Red tide di perairan Indonesia, Lipi, Jakarta, p.82.

Rabalais, N.N., Turner, E.R., Diaz, R.J., \& Justic, D. (2009). Global change and eutrophication of coastal waters. Journal Marine Sciene, 66(7), 1528-1537.
Santoso, A.D. (2006). Kualitas nutrien perairan teluk hurun lampung. Jurnal Teknik Lingkungan, 7(2),140144

Simanjuntak, M. (2012). Hubungan Faktor Lingkungan Kimia, Fisika Terhadap Distribusi Plankton di Perairan Belitung Timur, Bangka Belitung. Jurnal Perikanan, 9(1), 31-45.

Smadya, T.J. \& Reynolds, C.S. (2001). Community assembly in marine phytoplankton : application of recent models to harmful dinoflagellate blooms. Journal Plankton Research, 23(5), 447-461.

Soedibjo, B.S. (2007). Fenomena kehadiran Skeletonema sp. di Perairan Teluk Jakarta.Jurnal IImu Kelautan, 12(3), 119-124.

Susana, T. (2000). Reaksi kimia dalam air laut dan sedimen perairan teluk lampung, kaitannya dengan senyawa nitrogen. Pesisir dan Pantai Indonesia IV. Lipi, Jakarta, p. 41-48.

Widiarti, R., \& Pratiwi, T. (2003). IMFS 2003, International Seminar on Marine and Fisheries, Jakarta, pp. 7378.

Yamaji, I.E. (1996). Illustration of The Marine Plankton of Japan. Hoikusha Publishing Co., Ltd. Osaka. Japan, p. 987.

Yuliana. (2012). Implikasi perubahan ketersediaan nutrien terhadap perkembangan pesat (blooming) fitoplankton di perairan teluk Jakarta. [Disertasi]. Bogor.Indonesia, Institut Pertanian Bogor

Zhou, H., Jiang, C., Zhu, L., Wang, X., Hu, X., Cheng, J., \& Xie, M. (2011). Impact of Pond and Fence Aquaculture on Reservoir Environment. Water Science and Engineering, 4(1), 92-100. 